\section{WINTER BIRD FEEDING AT TOGO, SASKATCHEWAN}

\author{
by W. J. C. MAY*
}

Our winter bird feeding program tarted small but is becoming very popular with birds and humans alike. The original feeder was Walter Krupp, $\mathrm{n}$ the village of Togo, and he is still he main bird feeder and watcher. $\mathrm{He}$ was joined by the late Charles Stone on is farm and now we have about a lozen farmers with well established eeding stations.

Obtaining sunflower seeds is pecoming increasingly difficult and expensive. Now retired, I have fallen heir to the task of locating, hauling and distributing seeds. In 1973 I made wo 400-mile round trips to Glenboro, Manitoba, and hauled over 4000 pounds of sunflower seeds. These we bagged in 50-pound bags. We also put out rapeseed for the redpolls, especially.

In February, 1974, the following birds were counted at my feeder located on our farm 4 miles north of Togo: Hairy Woodpecker, 2; Downy Woodpecker, 2; Blue Jay, 2; Blackcapped Chickadee, 8; Evening Grosbeak, 70+: Pine Grosbeak, 22: Common Redpoll, 45; Hoary Red poll, 5 and, our biggest thrill, Graycrowned Rosy Finch, that rare straggler from the mountains, 2. On March 2, the first two Tree Sparrows arrived but by March 11, the Pine Grosbeak numbers had dropped to two. However, a new invasion of 200 Evening Grosbeaks appeared on March 21.

${ }^{*}$ Togo, Sask.

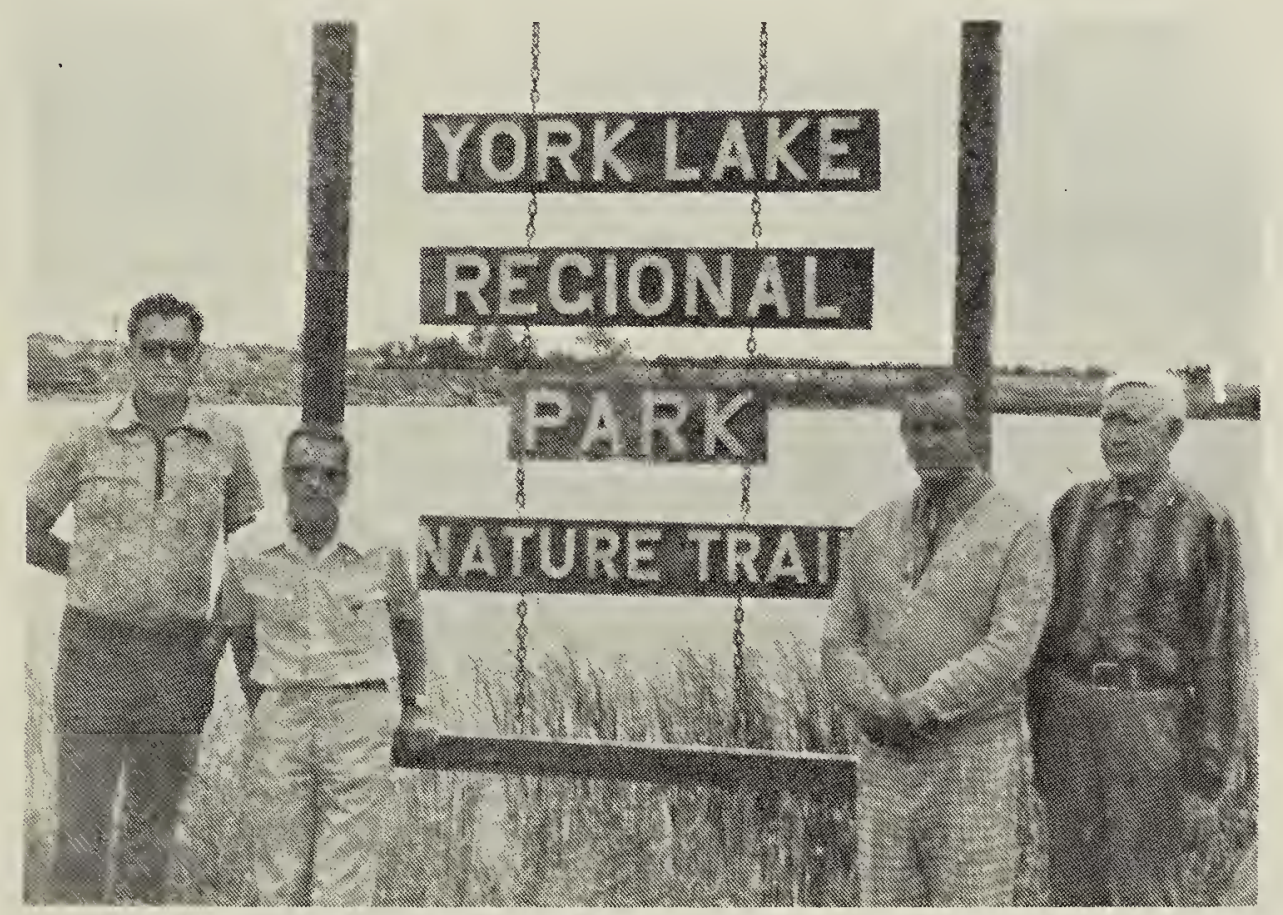

\title{
NEW NATURE TRAIL — YORKTON, SASKATCHEWAN
}

The Annual Family Day at the York Lake Regional Park on Sunday, August 1, 1974, marked the opening of the new Nature Trail laid out by the Yorkton Tatural History Society. It extends for one mile through a variety of habitat, inluding margins of lake and marsh. Fourteen lectern-like posts contain detailed escriptions, under plastic, of the plants and birds to be expected at each station, nd how they relate to the environment. The trail is named the Isabel M. Priestly rail, in honour of the founder of the Blue Jay and the Yorkton Natural History ciety.

Shown at the entrance to the trail are, from left to right, Lorne Lepp and Larry lorgotch of the Yorkton Natural History Society, G. C. Rathwell, supervisor of askatchewan Regional Parks, and Dr. C. J. Houston, chairman of the York Lake egional Park authority. 
